\title{
Changes in the nuclear distribution of DNA polymerase alpha and PCNA/cyclin during the progress of the cell cycle, in a cell-free extract of
} Xenopus eggs

\author{
CHRISTOPHER HUTCHISON and IAN KILL \\ Department of Genetics and Developmental Biology, School of Biological Sciences, University of Sussex, Brighton, Sussex BNI 9QG, UK
}

\begin{abstract}
Summary
The nuclear distribution of DNA polymerase alpha and PCNA/cyclin in embryonic nuclei has been investigated, in a cell-free extract of Xenopus eggs that recapitulates a basic cell-cycle in vitro, by indirect immunofluorescence microscopy. Both antigens co-distribute with the chromatin in Sphase nuclei; however, as DNA replication is completed and nuclei progress into a $G_{2}$ state anti-PCNA fluorescence disappears and anti-DNA polymerase alpha fluorescence becomes resolved into bright spots. These spots are initially associated with the chromatin strands and can be seen to share both anti-PCNA and anti-DNA polymerase alpha fluorescence, but as anti-PCNA fluorescence fades the spots become dissociated from the chromatin and are redistributed throughout the nucleus until they
\end{abstract}

are dispersed during nuclear envelope breakdown. The loss of anti-PCNA fluorescence and displacement of anti-DNA polymerase alpha fluorescence from the chromatin can be prevented by inhibiting DNA synthesis with aphidicolin. Under these conditions both antigens remain associated with the chromatin even after nuclear envelope breakdown and lamin dispersal. The association of these antigens with mitotic figures appears to be functional, as both biotin-11-dUTP and $\left.{ }^{32} \mathrm{P}\right] \mathrm{dCTP}$ can be incorporated efficiently into DNA during the mitotic period.

Key words: DNA polymerase alpha, PCNA/cyclin, nuclear antigens, cell cycle, DNA replication.

\section{Introduction}

S-phase nuclei are highly organized structures that contain several clearly defined compartments, and it seems likely that this structural organization is essential for the efficient initiation and completion of DNA replication. For example, using fluorescent antibodies to the thymidine analogue BrdUTP it has been shown that initiation sites occur synchronously at discrete sites within S-phase nuclei (Nakamura et al. 1986), a view that is supported by the observation that nascent DNA and replication origins are tightly associated with the salt-insoluble nuclear matrix and are not removed from nuclei with bulk chromatin after nuclease digestion and electrophoresis (Smith \& Berezney, 1982; Dijkwel et al. 1986; Jackson \& Cook, 1986a).

The behaviour of replication enzymes during the cell cycle also indicates that structural organization is required for the initiation of DNA replication. DNA polymerase alpha, which is apparently required for lagging strand synthesis (Focher et al. 1988; Prelich \& Stillman, 1988), and PCNA, the auxiliary protein of DNA polymerase delta (Bravo et al. 1987; Prelich et al. 1987), both appear to have characteristic nuclear distri- butions during S-phase. Immunolocalization studies indicate that DNA polymerase alpha is distributed throughout the nucleoplasm during interphase (Bensch et al. 1982); however, during S-phase a subpopulation of the enzyme becomes tightly associated with the nuclear matrix, so much so that its activity is stably maintained through extraction (Smith \& Berezney, 1983; Jackson \& Cook, 1986b). Similarly, PCNA has a uniform nucleoplasmic distribution during interphase and in quiescent cells, but upon entry into S-phase $20-30 \%$ of the protein becomes specifically associated with the sites of replication and cannot be removed following Triton extraction of the nuclei (Bravo \& MacDonald-Bravo, 1987).

The mechanisms by which such changes are brought about remain unclear. However, the development of a cell-free system that faithfully reproduces such changes in vitro would greatly facilitate their study. We have recently described a cell-free extract of Xenopus eggs that undergoes multiple rounds of DNA replication in vitro (Hutchison et al. 1987). The replication in this system is dependent on nuclear structure, while reinitiation is dependent on mitotic events (Hutchison et al. 1988). Mitosis in this system requires extensive protein synthesis. However, in the presence of protein synthesis 
inhibitors only a single round of DNA replication occurs and the nuclei enter and become arrested in a $\mathrm{G}_{2}$-like state. In the present study we have examined the nuclear localization of DNA polymerase alpha and PCNA with specific antibodies in the cell-free system. We report changes in the distribution of both antibodies as nuclei move from an S-phase to a $\mathrm{G}_{2}$ state. These changes are apparently not regulated by cytoplasmic signals but can be delayed by slowing the rate of replication.

\section{Materials and methods}

\section{Preparation of extracts}

Extracts were prepared from unfertilized Xenopus eggs according to the method described by Hutchison et al. (1988). Briefly, eggs were collected from mature female frogs after a single injection of human chorionic gonadotrophin (650i.u.) $16 \mathrm{~h}$ before use. After dejellying, the eggs were rinsed three times in saline tap water, twice in distilled water and twice in ice-cold extraction buffer $(20 \mathrm{~mm}-\mathrm{Hepes}, \mathrm{pH} 7 \cdot 5,100 \mathrm{~mm}-\mathrm{KCl}, 5 \mathrm{~mm}$ $\mathrm{MgCl}_{2}, 2 \mathrm{~mm}$-2-mercaptoethanol). The eggs were then packed into $5 \mathrm{ml} \mathrm{Beckman}$ centrifuge tubes and excess buffer was removed before centrifugation for $10 \mathrm{~min}$ at $10000 \mathrm{~g}$. The soluble extract was removed and treated with $5 \mu \mathrm{g} \mathrm{ml}^{-1}$ cytochalasin B before being centrifuged a second time at $10000 \mathrm{~g}$ for $10 \mathrm{~min}$. The final extract was made 80 Kallekrein units $\mathrm{ml}^{-1}$ with aprotinin and used immediately.

\section{Preparation of maturation promoting factor (MPF)}

MPF was prepared by a modification of the method of $W_{u} \&$ Gerhart (1980). Briefly, unfertilized eggs were disrupted by gentle homogenization on ice in the following buffer (EB): $80 \mathrm{~mm}$ - $\beta$-glycerophosphate, $20 \mathrm{~mm}$-EGTA, $15 \mathrm{~mm}-\mathrm{MgCl}_{2}$, $1 \mathrm{~mm}$-dithiothreitol (DTT), $0 \cdot 3 \mathrm{mM}$-ATP $\gamma \mathrm{S}, 10 \mu \mathrm{g} \mathrm{ml}^{-1}$ each of pepstatin $A$, leupeptin and aprotinin, and $1 \mathrm{~mm}$-phenylmethylsulphonyl fluoride (PMSF). The extract was clarified by centrifugation at $100000 \mathrm{~g}$ for $1 \mathrm{~h}$ at $4^{\circ} \mathrm{C}$ and frozen in liquid nitrogen.

\section{Preparation of demembranated sperm heads}

Sperm at concentrations of $10^{6} / 100 \mu \mathrm{l}$ in SUNaSp (Gurdon, 1976) were demembranated by treatment with phosphatidylcholine as described (Hutchison et al. 1987).

\section{Indirect immunofluorescence microscopy}

Samples were prepared for immunofluorescence microscopy as described (Hutchison et al. 1988). Samples (10 $\mu \mathrm{l})$ of egg extract containing $10^{4}$ sperm heads were pulse-labelled for 10 min periods with biotın-11-dUTP $(1 \mu \mathrm{l}$ of $40 \mu \mathrm{M}$, Biorad) at $22^{\circ} \mathrm{C}$. Reactions were stopped by adding $200 \mu \mathrm{l}$ of EGS (ethylene glycol bis(succinic acid $N$-hydroxysuccinimide ester)) and incubating for $30 \mathrm{~min}$ at $37^{\circ} \mathrm{C}$. The nuclei were recovered by centrifugation through $25 \%$ glycerol, at $2000 \mathrm{revs}^{-1} \mathrm{~min}^{-1}$ in an MSE $2 \mathrm{~L}$ centrifuge, onto glass coverslips. The coverslips were then incubated overnight with antibody at $4^{\circ} \mathrm{C}$ (monoclonal anti-DNA polymerase alpha was used as an undiluted hybridoma supernatant from the SJK 132 cell line (Tanaka $e t$ al. 1982); monoclonal anti-lamin ascitic fluid was used at a $1 / 500$ dilution in phosphate-buffered saline (PBS) and was supplied by Dr R. Stick (Stick \& Hausen, 1985); anti-PCNA antibodies were obtained from a human auto-immune serum and used at a dilution of $1 / 2000$ in PBS (Tan, 1982)). The coverslips were rinsed in PBS before the addition of the second antisera (FITC-rabbit anti-mouse immunoglobulin (Ig) diluted $1 / 20$ in PBS or TRITC/FITC-rabbit anti-human Ig diluted $1 / 20$ in PBS) and/or Texas Red-streptavidin (diluted $1 / 50$ in PBS) and incubated for a further $4 \mathrm{~h}$ at $4^{\circ} \mathrm{C}$. Finally, the coverslips were rinsed in PBS and mounted on glass slides in $50 \%$ glycerol/PBS containing $1 \mu \mathrm{g} \mathrm{ml}^{-1}$ DAPI. Slides were viewed using a Zeiss photomicroscope III fitted with a sidemounted u.v. arm. (N.B. All PBS solutions contained $1 \%(\mathrm{v} / \mathrm{v})$ foetal calf serum).

\section{$\left.{ }^{32} P\right] d C T P$-labelling studies}

In order to estimate the amount of DNA synthesis occurring in each extract, $30 \mu \mathrm{l}$ samples containing $3 \times 10^{4}$ sperm heads were labelled for various periods of time with $1.5 \mu \mathrm{Ci}(1.5 \mu \mathrm{l}$ in SUNaSp) of $\left.{ }^{32} \mathrm{P}\right] \mathrm{dCTP}$ (sp. act. $3000 \mathrm{Ci} \mathrm{mmol}^{-1}, \mathrm{NEN}$ ) at $22^{\circ} \mathrm{C}$. Reactions were terminated by adding $30 \mu \mathrm{l}$ of stopping solution (Hutchison et al. 1987), and placing samples on ice. Labelled samples were prepared for agarose gel electrophoresis as described (Hutchison et al. 1987) and the incorporation of $\left[{ }^{32} \mathrm{P}\right] \mathrm{dCTP}$ into DNA was determined by cutting out the labelled bands and counting in a Beckman LS 500 liquid scintillation counter.

\section{Results}

Changes in the distribution of nuclear antigens during the first cell cycle in vitro

During the first cell cycle in vitro, pronuclei start to enter S-phase at approximately $20 \mathrm{~min}$ after the addition of sperm heads to egg extracts. The formation of S-phase nuclei in vitro is characterized by the accumulation of nuclear membranes around decondensing DNA (Lohka \& Masui, 1983; Blow \& Laskey, 1986; Hutchison et al. 1988), and by the acquisition of nuclear antigens such as nuclear lamins, DNA polymerase alpha and PCNA/cyclin (Fig. 1). The accumulation of lamins within pronuclei, detected by indirect immunofluorescence, occurred slightly before the accumulation of DNA polymerase alpha and PCNA, both of which appeared to enter nuclei at the same time. However, all three antigens were detected in the majority of nuclei 5-10 min before any DNA synthesis (detected by biotin-11-dUTP incorporation) was observed.

The pattern of staining obtained with anti-lamin antibodies in S-phase nuclei differed from the patterns obtained with both anti-PCNA and anti-DNA polymerase alpha antibodies. Double immunofluorescence studies indicated that while anti-lamin antibodies stained S-phase nuclei with a characteristic halo-like peripheral pattern, accompanied by ridges of stain within the nucleus (Fig. 1B), anti-PCNA antibodies gave rise to much more uniform fluorescence (Fig. 1E) characteristic of the fluorescence patterns obtained with DAPI (Fig. 1A,D), and biotin-11-dUTP (Fig. 1C). Similarly, the pattern obtained with anti-DNA polymerase alpha antibodies was also uniform throughout the $\mathrm{S}$-phase nucleus (Fig. 1F) and superimposed precisely over the anti-PCNA stain.

Other investigators have reported that PCNA displays a punctate pattern of fluorescence in S-phase nuclei, similar to patterns obtained with antibodies recognizing BrdUTP (Bravo \& MacDonald-Bravo, 1987). This pattern varied with the method of fixation but could be 
interpreted as showing a localization of PCNA at the sites of DNA replication. We do not observe such patterns of fluorescence with either PCNA or DNA polymerase antibodies in early S-phase nuclei. However, these nuclei are relatively small and it has been estimated that in order to complete $\mathrm{S}$-phase within $30 \mathrm{~min}, 100000$ synchronous initiations must occur in each one (Blow \& Watson, 1987). Thus in contrast to somatic nuclei, it seems unlikely that individual sites of replication could be distinguished under the light microscope.

Usually the first S-phase lasted approximately $30 \mathrm{~min}$ and was followed by a $G_{2}$ period. $G_{2}$ nuclei were characterized by rapid swelling accompanied by separation of the chromatin into distinct strands (Fig. 1G) and the termination of biotin-11-dUTP incorporation (Fig. 1I). The intensity of staining of anti-lamin antibodies did not vary between $\mathrm{S}$-phase and $\mathrm{G}_{2}$ nuclei, even though $\mathrm{G}_{2}$ nuclei had a much larger surface area (Fig. $1 \mathrm{H}, \mathrm{N}$ ). In contrast, following EGS fixation PCNA stain almost disappeared in $\mathrm{G}_{2}$ nuclei (Fig. $1 \mathrm{~K}$ ), while the intensity of DNA polymerase alpha antibody stain decreased markedly and the pattern became restricted to small spots initially surrounding the chromatin strands (Fig. 1L). The changes in distribution of PCNA and DNA polymerase alpha were independent of mitotic events and still occurred in the presence of cycloheximide (Fig. 1M-R). Nuclei incubated in cycloheximide-treated extracts become arrested in a $\mathrm{G}_{2}$ state (Hutchison et al. 1988 ). During this prolonged $G_{2}$ period the spots of antiDNA polymerase alpha fluorescence dissociated from the chromatin and were redistributed throughout the nucleoplasm, where they appeared to be larger but less abundant (Fig. 1R). The redistribution of the polymerase from the chromatin to the nucleoplasm also occurred in extracts undergoing normal cell cycle events, although as $\mathrm{G}_{2}$ was quite often short in these extracts it was easier to observe this redistribution in extracts treated with cycloheximide.

A typical sequence of the changes in distribution of DNA polymerase alpha, as nuclei progress from S-phase, through $G_{2}$ and into mitosis is illustrated in Fig. 2. During S-phase (Fig. 2A), as stated above, it was difficult to discern discrete patterns of fluorescence, but polymerase alpha co-distributed precisely with the DNA. As nuclei entered $G_{2}$ and the chromatin started to separate, the distribution of polymerase alpha appeared to change and could be seen as bright foci that aligned the chromatin strands (Fig. 2B). As nuclei progressed through $G_{2}$ separation of the chromatin became more extensive and the spots of polymerase started to dissociate from the chromatin. Thus in Fig. $2 \mathrm{C}$ some chromatin strands can be seen to have associated polymerase alpha (arrow $a$ ), other strands have no associated polymerase alpha (arrow $b$ ), while some polymerase alpha accumulates in areas with no chromatin (arrow $c$ ). Towards the end of the $G_{2}$ phase most of the polymerase had dissociated from the chromatin and was distributed throughout the nucleoplasm (Fig. 2D). This was dispersed following nuclear envelope breakdown (Fig. 2E).

Double immunofluorescence microscopy was used in order to determine whether PCNA co-localized with the polymerase alpha stained-spots. PCNA was still detectable in early $\mathrm{G}_{2}$ nuclei and in such nuclei both antiPCNA and anti-DNA polymerase alpha antibodies gave rise to spotty patterns of fluorescence (Fig. 3A,B). The majority of these spots shared both FITC and TRITC
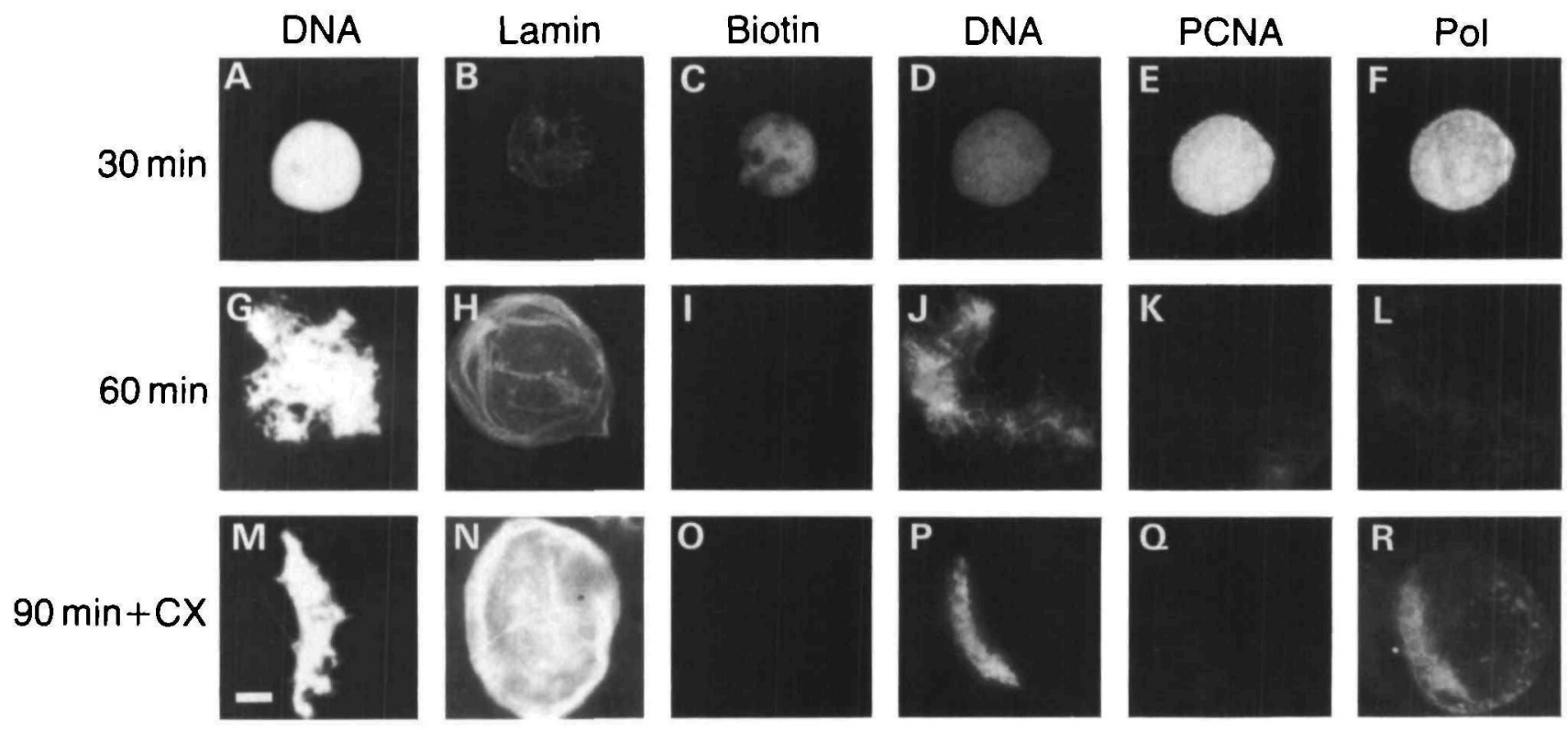

Fig. 1. Double indirect immunofluorescence microscopy of S-phase and $G_{2}$ nuclei. Sperm heads $\left(10^{5} / 100 \mu l\right)$ were incubated in egg extracts in either the presence or absence of cycloheximide (CX). During the final $10 \mathrm{~min}$ of the incubation the extracts were labelled with $4 \mu \mathrm{M}$-biotin-11-dUTP and then fixed in EGS. Each sample was triple-labelled with DAPI (A,D,G,J,M,P) and monoclonal antibodies to lamins $(B, H, N)$, and DNA polymerase alpha (Pol; $F, L, R)$, polyclonal antibodies to $P C N A(E, K, Q)$ or Texas Red-streptavidin (C,I,O). Bar, $5 \mu \mathrm{m}$. 

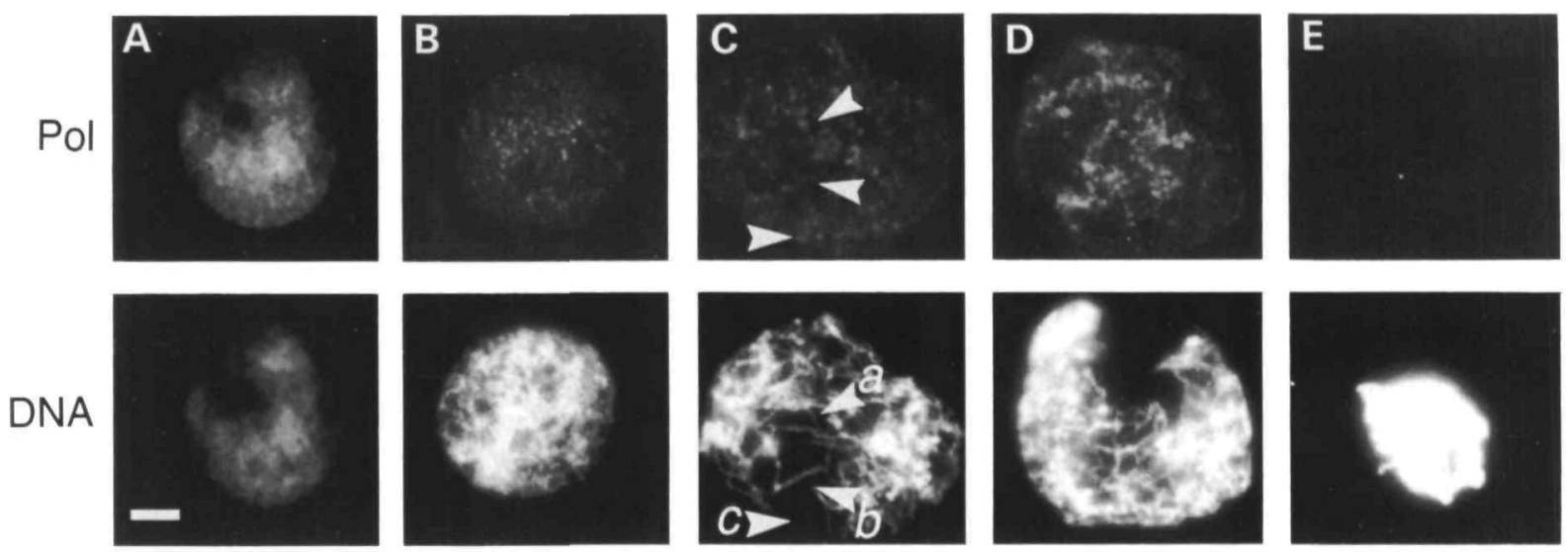

S

$\mathrm{G}$

M

Fig. 2. Changes in fluorescence patterns obtained with anti-DNA polymerase alpha antibodies during the progress of the cell cycle. Nuclei were incubated in egg extracts for 40 (A), 50 (B), 60 (C), 70 (D) or $80 \mathrm{~min}$ (E) before fixation in EGS. Each preparation was stained with DAPI to reveal the distribution of DNA and with monoclonal anti-DNA polymerase alpha antibodies (Pol). S, S-phase nuclei; $\mathrm{G}_{2}, \mathrm{G}_{2}$ nuclei; $\mathrm{M}$, mitotic figures. Arrowheads $a-c$ show the relative positions of DNA and DNA polymerase alpha in a nucleus (C). Bar, $5 \mu \mathrm{m}$.
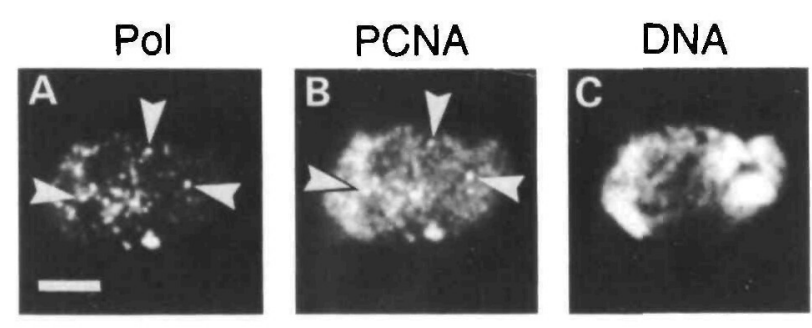

Fig. 3. Co-localization of DNA polymerase alpha with PCNA in early $G_{2}$-phase nuclei. Nuclei were isolated from egg extracts after incubation for $50 \mathrm{~min}$ at $22^{\circ} \mathrm{C}$ followed by fixation in EGS. Nuclei were stained with DAPI (C); polyclonal anti-PCNA antibodies (B); and monoclonal antiDNA polymerase alpha antibodies (A). Arrowheads show the relative positions of spots of PCNA fluorescence and DNA polymerase alpha fluorescence. Bar, $5 \mu \mathrm{m}$.

fluorescence (see arrows, Fig. 3A,B), indicating that PCNA and DNA polymerase alpha co-localized within the same structure.

The timing of the changes in distribution of PCNA and DNA polymerase alpha are illustrated in Fig. 4. Fig. 4A shows such changes in distribution occurring in nuclei undergoing normal cell cycle events. As nuclei enter $G_{2}$ (reflected by termination of biotin-11-dUTP incorporation) PCNA fluorescence starts to disappear, although this disappearance lags behind the cessation of biotin incorporation by $5-10 \mathrm{~min}$. This is better illustrated in Fig. 4B, which shows the distribution of nuclear antigens in cycloheximide-treated extracts. PCNA fluorescence fades and disappears from nuclei as they enter and become arrested in $\mathrm{G}_{2}$. At the same time DNA polymerase alpha is redistributed to the nucleoplasm. As nuclear envelope breakdown (NEBD) does not occur in these extracts, these changes are presumably associated with termination rather than mitosis. In extracts where mitosis does occur, DNA polymerase alpha stain disappears with lamin dissolution and nuclear membrane

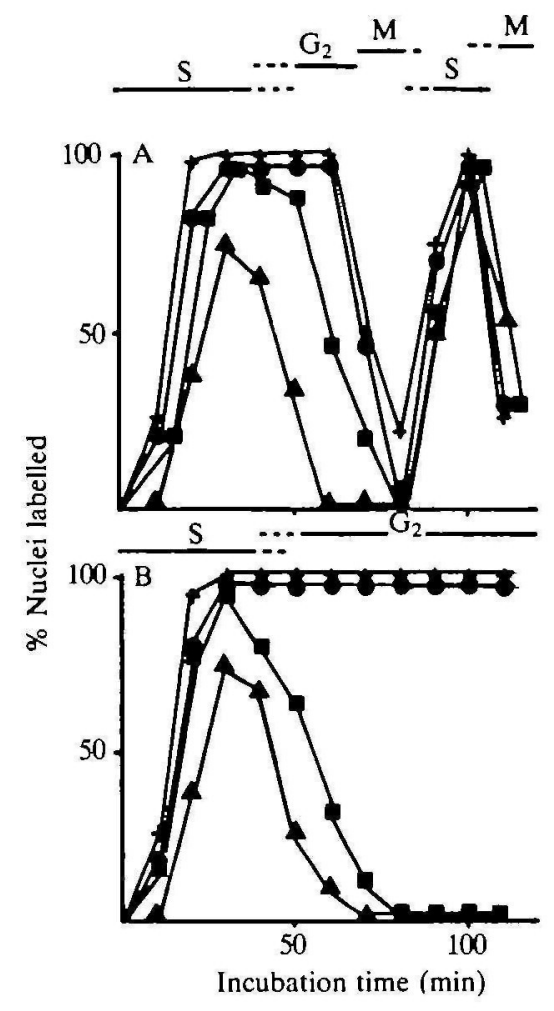

Fig. 4. Changes in the distribution of nuclear antigens during the progress of the cell cycle. Sperm heads were incubated in egg extracts either in the presence (B) or absence $(A)$ of $10 \mu \mathrm{g} \mathrm{ml}^{-1}$ cycloheximide. Samples of each extract were pulse-labelled with biotin-11-dUTP at $10 \mathrm{~mm}$ intervals, then fixed 10 min later in EGS. Nuclei were prepared for fluorescence microscopy and stained for PCNA distribution $(\boldsymbol{\square})$, DNA polymerase alpha distribution $(\mathbf{O})$, lamin distribution $(+)$ or distribution of biotin-11-dUTP (A); 200 nuclei were scored on each slide for the presence or absence of label. S. Period during which nuclei with an $\mathrm{S}$. phase morphology predominated; $\mathrm{G}_{2}$, period during which nuclei with $\mathrm{a}_{2}$ morphology predominated; $M$, period during which mitotic figures predominated. 

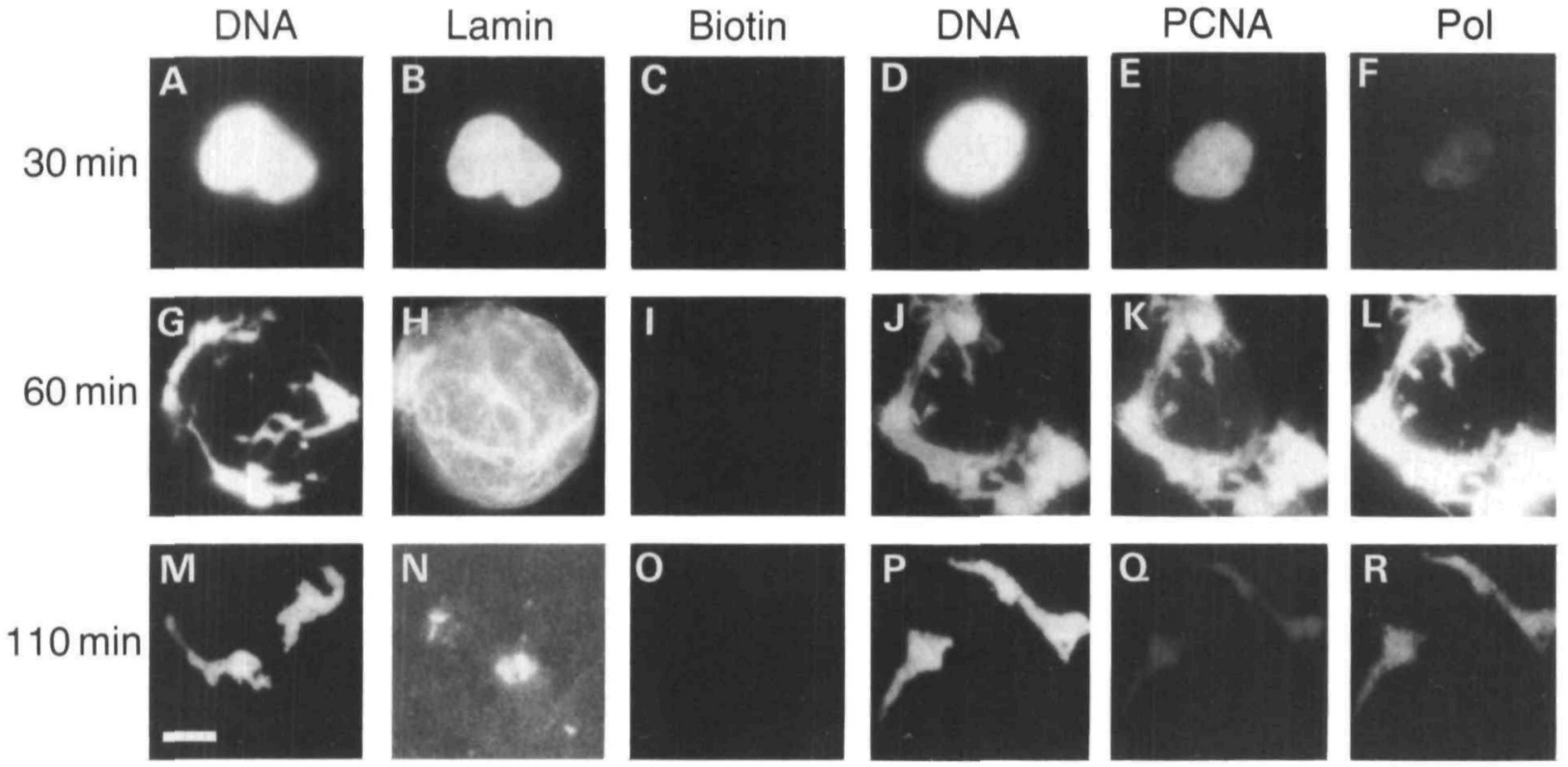

Fig. 5. The distribution of nuclear antigens in extracts treated with aphidicolin. Spern heads were incubated in egg extracts containing $50 \mu \mathrm{g} \mathrm{ml}^{-1}$ aphidicolin. During the final $10 \mathrm{~min}$ of incubation the extracts were pulse-labelled with $4 \mu \mathrm{m}-$ biotin-11dUTP, then fixed in EGS. Nuclear preparations were stained with DAPI (A,D,G,J,M,P) and monoclonal anti-lamin antibodies $(B, H, N)$, monoclonal anti-DNA polymerase alpha antibodies $(F, L, R)$, polyclonal anti-PCNA antibodies $(E, K, Q)$ or Texas Red-streptavidin $(\mathrm{C}, 1, \mathrm{O})$. Incubation times are given in min. Bar, $50 \mu \mathrm{m}$.

breakdown. However, both PCNA and DNA polymerase alpha rapidly reassociate with re-forming nuclei at the end of mitosis (Fig. 4A).

\section{The effect of aphidicolin on entry into $S$-phase, $G_{2}$ and mitosis}

The changes in distribution of both anti-PCNA and antiDNA polymerase alpha antibodies as nuclei move from a replicative to a post-replicative state could reflect modifications to replication complexes following the termination of DNA replication. Thus if DNA replication was inhibited and termination did not occur it might be expected that changes in antigenic distribution might also be inhibited. To test this, both nuclear morphology and the distribution of PCNA and DNA polymerase alpha were observed in nuclei formed in aphidicolin-treated extracts.

Aphidicolin was added to extracts at a concentration of $50 \mu \mathrm{g} \mathrm{ml}^{-1}$. Under these conditions nuclear assembly still occurred at the same rate as in control extracts, but DNA synthesis (measured by $\left[{ }^{32} \mathrm{P}\right] \mathrm{dCTP}$ incorporation into DNA) was completely inhibited. Thus $20 \mathrm{~min}$ after the addition of sperm heads to egg extracts, nuclei with a continuous membrane (not shown), decondensed DNA and extensive lamina were obtained (Fig. 5A,B). However, despite the accumulation of both PCNA and DNA polymerase alpha within such nuclei (Fig. 6E,F), as expected no biotin-11-dUTP incorporation could be detected (Fig. 6C). After $50 \mathrm{~min}$ these nuclei began to swell rapidly, but instead of separating into thread-like strands the chromatin was observed as thickened fibres that, although clearly excluded from some areas of the nucleus, did not appear to have the structure of $G_{2}$ chromatin (Fig. 5G; compare with Fig. 1J); both micrographs are at the same magnification and show nuclei fixed at the same time. However, whereas Fig. 1J clearly shows DNA distributed as fibrils of approximate diameter $0.3 \mu \mathrm{m}$, Fig. $5 \mathrm{G}$ shows amorphous clumps of DNA. Again, in contrast to the controls, both PCNA and DNA polymerase alpha antibodies continued to reveal bright patterns of fluorescence associated with these thickened chromatin fibres (Fig. 5J,K,L).

Typically, in extracts treated with $50 \mu \mathrm{g} \mathrm{ml}^{-1}$ aphidicolin, NEBD was delayed by $40-50 \mathrm{~min}$, during which time the intensity of chromatin-associated PCNA and DNA polymerase alpha fluorescence did not alter (not shown). After $110 \mathrm{~min}$ in the extract illustrated, NEBD (not shown) and lamin dispersal occurred (Fig. $5 \mathrm{~N}$ ). However, there was no evidence of chromosome condensation or separation of chromatids; instead the chromatin remained as a single thick mass (Fig. 5M). Both PCNA and DNA polymerase alpha continued to associate with such chromatin masses (Fig. 5P,Q, R), although, as expected, no biotin-11-dUTP incorporation was detected (Fig. 5O).

One interpretation of the continued association of both PCNA and DNA polymerase alpha with chromatin after nuclear envelope breakdown is that, in the absence of termination, replication complexes remain stably associated with replication forks. If so, it should be possible to detect DNA synthesis under conditions that are permissive for elongation. At $5 \mu \mathrm{g} \mathrm{ml}^{-1}$, aphidicolin slows but does not inhibit DNA synthesis in egg extracts. Nuclear assembly and the accumulation of replication antigens occurs at comparable rates to controls although biotin-11dUTP incorporation is not detected until 40 min after the addition of sperm heads to egg extracts. In control 

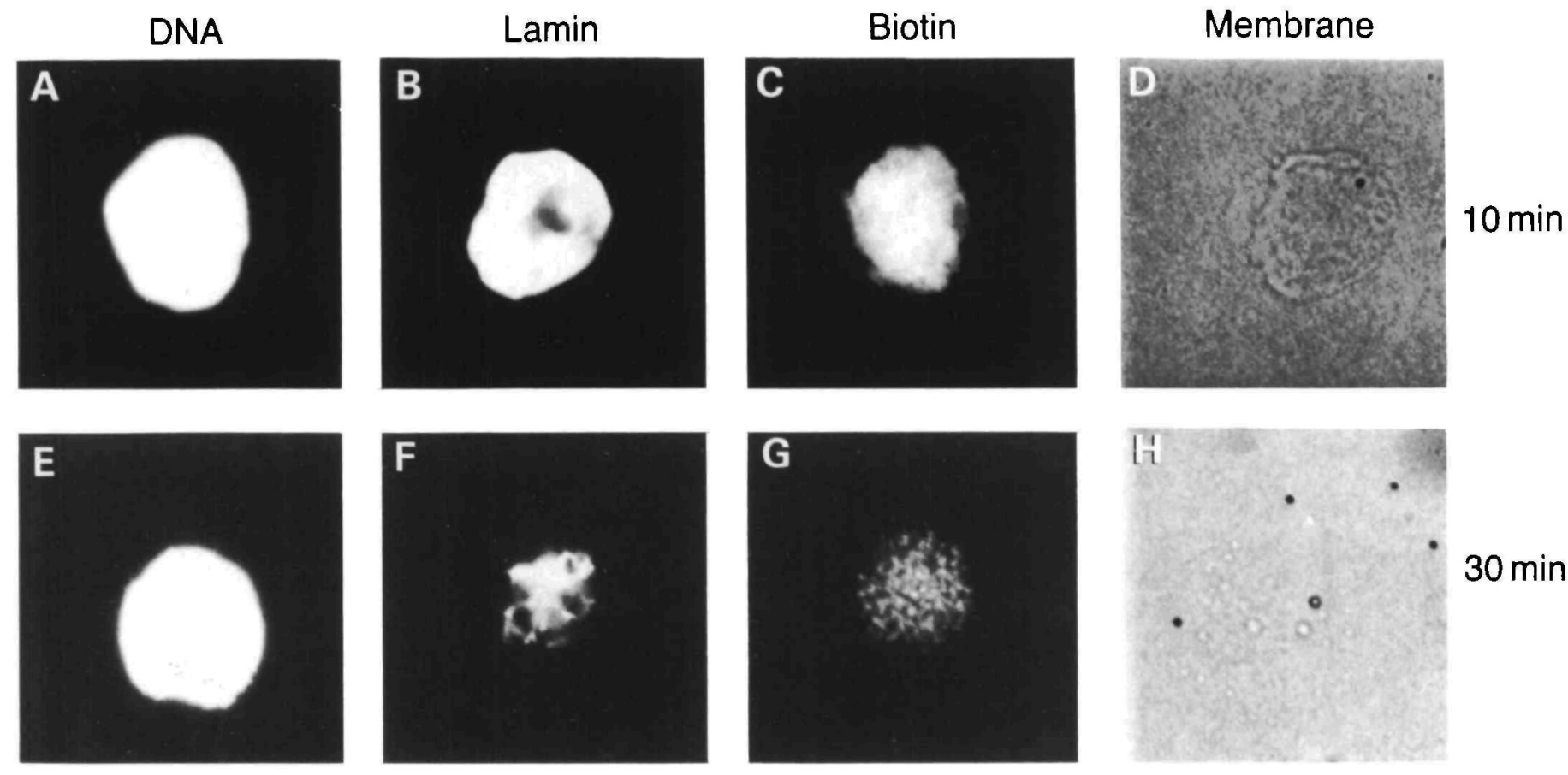

$30 \mathrm{~min}$
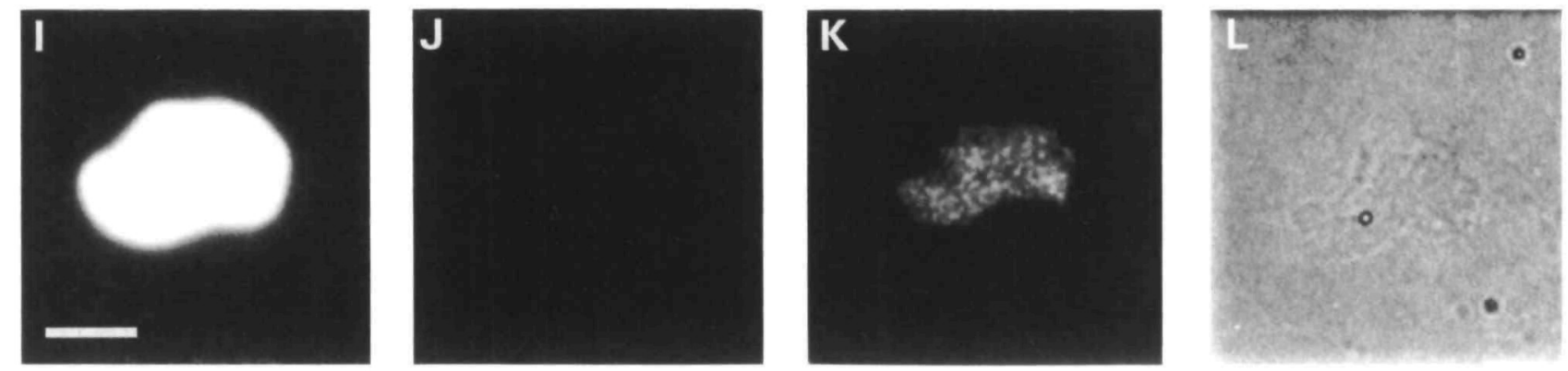

$60 \mathrm{~min}$

Fig. 6. DNA replication in nuclei undergoing nuclear envelope breakdown. Sperm heads were incubated in extracts containing $5 \mu \mathrm{g} \mathrm{ml}^{-1}$ aphidicolin and $50 \mu \mathrm{g} \mathrm{ml}^{-1}$ cycloheximide. After $50 \mathrm{~min}$ an equal volume of MPF (diluted $1+2$ in EB) was added and the incubation continued. Samples were pulse-labelled with biotın-11-dUTP and fixed $10 \mathrm{~min}$ later. Nuclear preparations were stained with DAPI (A,E,I), monoclonal anti-lamin antibodies (B,F,J) and Texas Red-streptavidin (C,G,K). Slides were examined under both fluorescence and DIC optics $(D, H, L)$ to reveal nuclear envelopes. Time after the addition of MPF in min (is shown on the left). Bar, $5 \mu \mathrm{m}$.

extracts nuclei terminate DNA replication after $30 \mathrm{~min}$ of synthesis; however, in aphidicolin-treated extracts, nuclei remain in $\mathrm{S}$-phase for $80 \mathrm{~min}$. Extracts containing $5 \mu \mathrm{g} \mathrm{ml}^{-1}$ aphidicolin were also made $50 \mu \mathrm{g} \mathrm{ml}^{-1}$ with cycloheximide to block protein synthesis and consequently mitosis. Fifty minutes after the addition of sperm heads (which was $10 \mathrm{~min}$ after biotin-11-dUTP incorporation was first detected) maturation promoting factor (MPF) was added in order to induce NEBD. NEBD and lamin dispersal started to occur $15 \mathrm{~min}$ later and was completed $30 \mathrm{~min}$ after the addition of MPF. Throughout this period and for $40 \mathrm{~min}$ afterwards the extracts were pulse-labelled with biotin-11-dUTP and nuclei were prepared for fluorescence microscopy. The results illustrated in Fig. 6 show that DNA synthesis, determined by biotin-11-dUTP incorporation, continued for at least $40 \mathrm{~min}$ after nuclear envelope breakdown. Fig. 6A-D shows a nucleus that was pulse-labelled with biotin-11dUTP for the $10-\mathrm{min}$ period following the addition of MPF. The lamina (Fig. 6B) and nuclear envelope (Fig. 6D) were still both extensive but no longer sur- rounded all of the DNA (Fig. 6A). Biotin-11-dUTP incorporation was extensive during this period, indicating considerable DNA synthesis (Fig. 6C). Thirty minutes after the addition of MPF, nuclear envelopes were no longer detectable (Fig. $6 \mathrm{H}$ ), although some lamin structures persisted (Fig. 6F). During the preceding 10-min period biotin-11-dUTP was still incorporated into DNA; however, this was detected as discrete spots of fluorescence (Fig. 6G) rather than the uniform stain described in Fig. 6D, implying that the rate of elongation had decreased. Sixty minutes after the addition of MPF both nuclear envelopes (Fig. 6L) and lamina (Fig. 6J) had been undetectable for over $20 \mathrm{~min}$. Despite this, a pulse label with biotin-11-dUTP still gave rise to incorporation at discrete spots throughout the chromatin mass (Fig. 6K).

Similar results were obtained in extracts undergoing normal mitotic cycles, where the addition of $5 \mu \mathrm{g} \mathrm{ml}^{-1}$ aphidicolin only delayed NEBD by $10 \mathrm{~min}$. In these extracts the chromatin did appear to separate into distinguishable figures (Fig. 7A), although these were 
clearly not condensed chromosomes as were obtained in control extracts (Fig. 7D). However, such figures incorporated both biotin-11-dUTP (Fig. 7F) and [ $\left.{ }^{32} \mathrm{P}\right] \mathrm{dCTP}$ efficiently (Fig. 8). In addition, density substitution
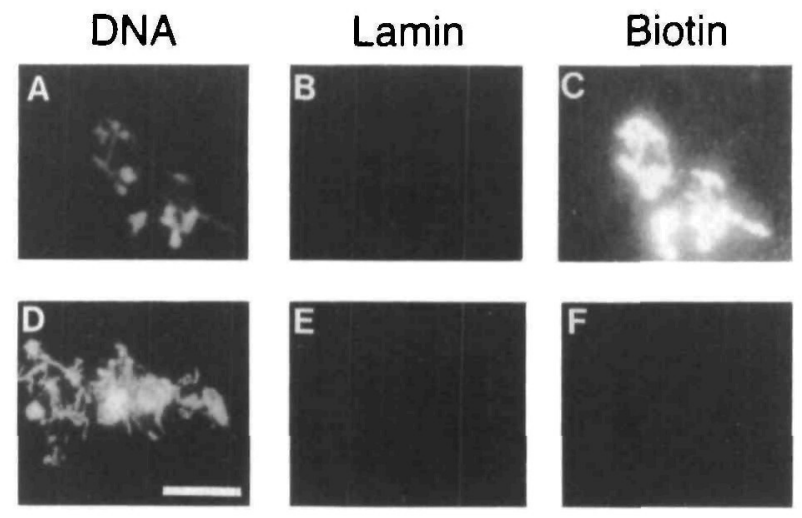

Fig. 7. Incorporation of biotin-11-dUTP into chromatin lacking nuclear envelopes. Sperm heads were incubated with egg extracts for $100 \mathrm{~min}$ at $22^{\circ} \mathrm{C}$ either in the presence $(\mathrm{A}-\mathrm{C}$ ) or absence (D-F) of $5 \mu \mathrm{g} \mathrm{m}^{-1}$ aphidicolin. Following NEBD the extracts were labelled with biotin-11-dUTP, then fixed in EGS. Preparations were stained with DAPI ( $A$ and D), monoclonal anti-lamin antibodies ( $B$ and $E$ ), and Texas Red-streptavidin ( $\mathrm{C}$ and $\mathrm{F}$ ). Bar, $5 \mu \mathrm{m}$.

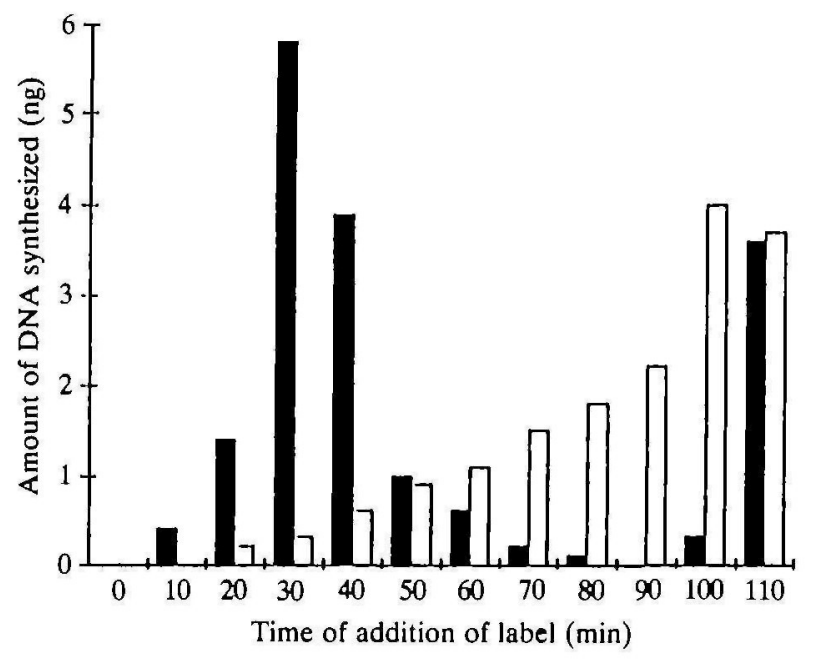

Fig. 8. The efficiency of DNA synthesis in aphidicolintreated extracts. Extracts containing sperm heads were pulselabelled for $10-$ min periods at 10 -min intervals with $\left[{ }^{32} \mathrm{P}\right] \mathrm{dCTP}$. The amount of DNA synthesis in each $10-\mathrm{min}$ period was determined following agarose gel electrophoresis of replication products as described (Hutchison et al. 1988). Open bars show the amount of DNA synthesis in each 10min period in extracts treated with $5 \mu \mathrm{g} \mathrm{ml}^{-1}$ aphidicolin. Filled bars show the pattern of synthesis in untreated extracts. Mitosis, measured in parallel samples by fluorescence microscopy, occurred between 80 and $100 \mathrm{~min}$ in control extracts and between 90 and $110 \mathrm{~min}$ in aphidicolintreated extracts. (N.B. Mitosis was asynchronous in aphidicolin-treated extracts, so that $100 \%$ NEBD only occurred in a small $(<10 \mathrm{~min})$ window between 90 and $100 \mathrm{~min}$.) experiments with BrdUTP indicated that this synthesis was semiconservative (not shown).

\section{Discussion}

The distribution of DNA polymerase alpha and PCNA in $S$-phase and $G_{2}$ nuclei

Both DNA polymerase alpha and PCNA appear to be associated with the chromatin of S-phase nuclei generated in vitro. Furthermore, as nuclei enlarge and the chromatin starts to separate during the progression from S-phase to $G_{2}$ each antigen can be seen to be organized at discrete sites in which one appears to be very closely associated with the other. By altering the rate of DNA synthesis, in extracts following the addition of $5 \mu \mathrm{g} \mathrm{ml}^{-1}$ aphidicolin, biotin-11-dUTP is also incorporated in chromatin at discrete sites. This pattern of incorporation is reminiscent of the pattern of BrdU incorporation into S-phase somatic nuclei (Nakamura et al. 1986), which apparently occurs at sites at which a number of replication proteins are stably associated with the chromatin (Bravo \& MacDonald-Bravo, 1987; 'de Bruyn Kops \& Knipe, 1988). Other studies have implicated a role for PCNA in the co-ordination of leading strand and lagging strand synthesis (Prelich \& Stillman, 1988), implying a close association between DNA polymerase alpha, DNA polymerase delta and PCNA. Thus the spots of chromatin-associated fluorescence in which both DNA polymerase alpha and PCNA co-localize may represent a replication complex or replicase.

As nuclei progress through $G_{2}$, PCNA fluorescence disappears. Similarly, it has been reported that PCNA fluorescence disappears from $G_{2}$ somatic cell nuclei (Celis \& Celis, 1985), although such patterns are dependent upon the method of fixation and appear to reflect the movement of antigen away from the sites of DNA replication (Bravo \& MacDonald-Bravo, 1987). Furthermore, immunoblotting indicates that nuclei isolated from our cell-free extracts do contain PCNA (Hutchison \& Kill, unpublished data). Hence, the absence of PCNA stain apparently represents either a modification or a change in distribution rather than a loss of antigen.

The loss of PCNA stain occurs at the same time as movement of DNA polymerase alpha away from the chromatin. Biochemical studies also indicate movement of DNA polymerases from fixed sites of DNA replication to the nucleoplasm as cells progress from S-phase to $G_{2}$ (Jackson \& Cook, 1986b; Smith \& Berezney, 1983). The changes in antigenic distribution can be inhibited by inhibiting DNA replication. Under these conditions both DNA polymerase alpha and PCNA continue to stain the chromatin brightly. Furthermore, as some mitotic events still occur in extracts in which DNA replication has been inhibited, it can be demonstrated that both antigens remain associated with unreplicated chromatin, despite the loss of both nuclear envelopes and lamina. As this association appears to be functional the association of a putative replication complex with S-phase chromatin must be very stable, implying that the dislocation of polymerases from the replicated chromatin is part of a 
termination mechanism that may involve specific modifications to the complex.

\section{Changes in antigenic distribution reflect regulative properties of the nucleus and not the cytoplasm}

The results reported here and elsewhere (Hutchison et al. 1988) suggest that the changes associated with entry into a $G_{2}$ state are a property of the nucleus and do not result from cytoplasmic signals. Nuclei undergo rapid nuclear swelling, cessation of DNA replication and changes in antibody staining in both the presence and absence of protein synthesis, and consequently mitotic signals. Furthermore, sperm heads added to extracts that contain $\mathrm{G}_{2}$ nuclei still form replication-competent nuclei (Graham \& Morgan, 1966; Hutchison et al. unpublished data) implying that the $G_{2}$ nuclear state does not result from cytoplasmic signals. In other cell-free extracts of Xenopus eggs that undergo a single round of DNA replication in vitro, nuclei within a common cytoplasmic environment initiate DNA replication asynchronously over a 2-h period (Blow \& Laskey, 1986; Blow \& Watson, 1987). Despite this asynchrony, Blow \& Watson (1987) have demonstrated that after initiation most nuclei remain in S-phase for a relatively constant period of approximately $30 \mathrm{~min}$. Thus, it seems that the timing of entry into a $\mathrm{G}_{2}$ state for each nucleus is dependent upon the timing of initiation. In the system described by Blow \& Laskey (1986) the asynchrony and pre-replicative lag is apparently a consequence of the addition of glycerol (Sheehan et al. 1988). In our system no glycerol is added and most nuclei enter S-phase over a 10 -min period. This synchrony within the nuclear population results in the majority of nuclei entering a $G_{2}$ state at the same time, which none the less is approximately $30 \mathrm{~min}$ after entering S-phase.

The loss of PCNA stain and redistribution of DNA polymerase alpha stain as nuclei enter a $G_{2}$ state can be delayed by altering the rate of DNA replication. If such changes represent modifications to a functional replication complex, then this indicates that such a modification occurs as a consequence of the completion of DNA replication and does not in itself terminate DNA replication. In contrast to these results, both our own (Hutchison et al. 1988) and other studies (Blow \& Watson, 1987) have indicated that not all nuclei that initiate DNA replication in cell-free extracts undergo a doubling of their DNA content. However, all nuclei in cycloheximide-treated extracts lose PCNA fluorescence within 60-70 $\mathrm{min}$. The simplest explanation for these two differing observations is that each initiation can support a strictly limited amount of DNA synthesis and that the completion of this synthesis leads to the inactivation of the replication complex. Consequently, such a model would require initiation to occur at a sufficient number of sites to ensure a doubling of the DNA content. The corollary of this is that nuclei that enter a $G_{2}$ state having failed to double their DNA content also fail to initiate replication at a sufficient number of sites.

\section{DNA replication and nuclear structure}

There is now clear evidence that initiation of DNA replication in eukaryotes requires nuclear structure (Blow \& Laskey, 1986; Blow \& Watson, 1987; Hutchison et al. 1987; Hutchison et al. 1988; Newport, 1987; Sheehan et al. 1988). Furthermore, other studies have implied that all nascent DNA is associated with the nucleoskeleton (Jackson \& Cook, 1986a) or with enzymes that are themselves associated with the nucleoskeleton (Nelson et al. 1986). It was therefore surprising that replication complexes could be stably maintained after nuclear envelope breakdown and lamin dispersal in extracts treated with aphidicolin. Plasmid replication has also been reported to occur in Xenopus embryos that were arrested in mitosis (Newport \& Kirschner, 1984), although it was not clear whether such plasmids had associated nuclear structures. Despite the detection of both putative replication complexes and DNA synthesis during mitosis, it is unlikely that any initiation was occurring, as this appears to be a single event in the first cell cycle in vitro (Blow \& Watson, 1987), which is associated with lamin polymerization (Hutchison et al. 1988). Furthermore, density substitution studies have revealed no evidence for precocious reinitiation. However, the finding that the propagation of the replication fork can occur in the absence of nuclear envelope and lamina does bring into question whether DNA replication occurs at fixed sites within embryonic nuclei.

We thank Professor Sydney Shall, Dr Christopher Ford and Professor Ron Laskey for helpful and stimulating discussions and Professor Shall for critical reading of the manuscript. We are also grateful to Dr Rodrigo Bravo for supplying us with human polyclonal anti-PCNA antibodies and to the CRC and SERC for financial support.

\section{References}

Bensch, K. G., Tanaka, S., Hu, S. A., Wang, S-Z. \& Korn, D. (1982). Intracellular localisation of human DNA polymerase alpha with monoclonal antibodies. F. biol. Chem. 257, 8391-8396.

Blow, J. J. \& LASKEY, R. A. (1986). Initiation of DNA replication in nucles and purified DNA by a cell-free extract of Xenopus eggs. Cell 47, 577-587.

BLow, J. J. \& Watson, J. V. (1987). Nuclei act as independent and integrated units of replication in a Xenopus cell-free DNA replication system. EMBO Y. 6, 1997-2002.

Bravo, R., Frank, R., Blundell, P. A. S Macdonald-Bravo, H. (1987). Cyclin/PCNA is the auxiliary proten of DNA polymerase delta. Nature, Lond. 326, 515-517.

Bravo, R. \& MacDonald-Bravo, H. (1987). Existance of two populations of cyclin/proliferating cell nuclear antigen during the cell cycle: Association with DNA replication sites. J. Cell Biol. 105, 1549-1554.

Celis, E. \& Celis, A. (1985). Cell-cycle dependent variations in the distribution of the nuclear protein cyclin in cultured cells. Proc. natn. Acad. Sci. U.S.A. 82, 3262-3266.

DE BRUYN KoPS, A. \& KNiPE, D. M. (1988). Formation of DNA replication structures in herpes virus-infected cells requires a viral DNA binding protein. Cell 55, 857-868.

Dijkwel, P. A., Wenink, P. W. \& Poddighe, P. J. (1986). Permanent attachment of replication origins to the nuclear matrix in BHK cells. Nucl. Acid Res. 14, 3241-3249.

Focher, F., Ferrari, E., Spadarl, S. \& Hubscher, U. (1988). Do DNA polymerase delta and alpha act coordinately as leading and lagging strand replicases? FEBS Lett. 229, 6-10.

Graham, C. F. \& Morgan, R. W. (1966). Changes in the cell-cycle during early amphibian development. Devl Biol. 14, 439-461. 
GuRDon, J. B. (1976). Injected nuclei in frog oocytes. Rate, enlargement and chromatin dispersal. J. Eimbryol. exp. Morph. 36, $523-540$.

Hutchison, C. J., Cox, R., Drepaul, R. S., Gomperts, M. \& FORD, C. C. (1987). Periodic DNA synthesis in cell-free extracts of Kenopus eggs. EMBO 7. 6, 2003-2010.

Hutchison, C. J., Cox, R. \& Ford, C. C. (1988). The control of DNA replication in a cell-free extract that recapitulates a basic cellcycle in vitro. Development 103, 553-566.

JACKSON, D. A. \& CoOK, P. R. (1986a). Replication occurs at a nucleoskeleton. EMBO J. 5, 1403-1410.

JACKSON, D. A. \& COOK, P. R. (1986b). Different populations of DNA polymerase in HeLa cells. 7. molec. Biol. 192, 77-86.

LOHKA, M. L. \& Masul, Y. (1983). Formation in vitro of sperm pronuclei and mitotic chromosomes induced by amphibian onplasmic components. Science 220, 719-721.

Nakamura, H., Morita, T. \& Sato, C. (1986). Structural organisation of replicon domains during DNA synthetic phase in the mammahian nucleus. Expl Cell Res. 165, 291-297.

Nelson, W. G., LiU, L. F. \& Coffey, D. S. (1986). Newly replicate DNA is associated with DNA topoisomerase II in cultured rat prostatic adenocarcinoma cells. Nature, Lond. 332, $187-189$

NEWPORT, J. W. (1987). Nuclear reconstitution in vitro: Stages of assembly around protein-free DNA. Cell 48, 205-217.

NEWPORT, J. W. \& KIRSCHNER, M. W. (1984) Regulation of the cellcycle during early Aenopus development. Cell 37, 731-742.

Prelich, G., Tan, C. K., Kostura, M., Matthews, M. B., So, A G., Downey, K. M. \& Stillman, B. (1987). Functional identity of proliferating cell nuclear antigen and a DNA polymerase delta auxiliary protein. Nature, Lond. 326, 517-520.

Prelich, G. \& Stillman, B. (1988). Coordinated leading and lagging strand synthesis during SV40 DNA replication in eitro requires PCNA. Cell 53, 117-126.

Sheehan, M. A., Mills, A. D., Sleeman, R. A., Laskey, R. A. \& BLow, J. J. (1988). Steps in the assembly of replication-competent nuclei in a cell free system from Xenopus eggs. J. Cell Biol. 14, $439-461$

Smith, H. C. \& Berezney, R. (1982). Nuclear matrix-bound deoxyribonucleic acid synthesis: an in vitro system. Biochemistry 21, 6751-6761.

SMITH, H. C. \& Berezney, R. (1983). Dynamic domains of DNA polymerase alpha in regeneratıng rat liver. Biochemistry 22 , 3042-3046.

Stick, R. \& Hausen, P. (1985). Changes in the nuclear lamina composition during early development of Xenopus laevis. Cell 41, $191-200$.

TAN, E. M. (1982). Autoantibodies to nuclear antigens (ANA): Their immunology and medicine. Adv Immmn. 33, 167-240.

Tanaka, S., Hu, S.-Z., Wang, T. S.-F. \& Korn, D. (1982). Preparation and preliminary characterisation of monoclonal antibodies against human DNA polymerase $\alpha$. f. biol. Chem. 257, 8386-8390.

Wu, M. \& Gerhart, J. (1980). Partial purification and characterisation of the maturation-promoting factor from eggs of Xenopus laevis. 7. Cell Biol. 79, 465-477.

(Received 26 January 1989 - Accepted, in revised form, 4 May 1989) 
